\title{
Penerapan Algoritma Genetika Untuk Optimasi Penjadwalan pada MTS Negeri 1 Pangkalpinang
}

\author{
Delpiah Wahyuningsih ${ }^{[1]^{*}}$, Ellya Helmud ${ }^{[2]}$ \\ Program Studi Teknik Informatika ${ }^{[1]}$, Program Studi Sistem Informasi ${ }^{[2]}$ \\ ISB Atma Luhur \\ Pangkalpinang, Indonesia \\ delphibabel@atmaluhur.ac.id ${ }^{[1]}$ ellyahelmud@atmaluhur.ac.id ${ }^{[2]}$
}

\begin{abstract}
Scheduling is a very important thing to do at school. The schedule, which is still being carried out manually at MTS Negeri 1 Pangkalpinang, requires time to manage teacher slots, classes, subjects, and times where in MTS teacher hours have been determined by the department of religion so that it takes quite a long time to process the formation of the schedule. This study aims to utilize genetic algorithms in optimizing scheduling in a short time. The genetic algorithm is an algorithm that is effective in dealing with scheduling. The results of data testing were carried out with $15,20,25$ and 30 subjects. Testing with 15 subjects took 19.56 seconds to form a schedule and there were no conflicting schedules, while with 20 data subjects the time to process the schedule formation took 42.15 seconds, 25 data with 94.07 seconds and 30 data with time 471.60. The average time required to process the data is $\mathbf{1 5 6 . 8 4 5}$ seconds.
\end{abstract}

Keywords- Scheduling, MTS Negeri 1 Pangkalpinang, Genetic Algorithm

\begin{abstract}
Abstrak-Penjadwalan merupakan hal yang sangat penting untuk dilakukan pada sekolah. Jadwal yang masih dilakukan secara manual pada MTS Negeri 1 Pangkalpinang ini membutuhkan waktu untuk mengatur slot guru, kelas, mata pelajaran, dan waktu dimana pada MTS jam guru telah ditentukan oleh departemen agama sehingga membutuhkan waktu yang cukup lama untuk memproses terbentuknya jadwal. Penelitian ini bertujuan untuk memanfaatkan algoritma genetika dalam mengoptimalkan pembuatan jadwal dengan waktu yang singkat. Algoritma genetika merupakan algoritma yang efektif dalam mengatasi pembuatan jadwal. Hasil dari pengujian data dilakukan dengan 15, 20, 25 dan 30 mata pelajaran. Pengujian dengan 15 mata pelajaran membutuhkan waktu 19,56 detik untuk terbentuknya jadwal dan tidak ada jadwal yang bentrok sedangkan dengan 20 data mata pelejaran waktu untuk memproses terbentuknya jadwal membutuhkan waktu 42,15 detik, 25 data dengan waktu 94,07 detik dan 30 data dengan waktu 471,60. Rata-rata waktu yang dibutuhkan untuk memproses data tersebut yaitu 156,845 detik.
\end{abstract}

Kata Kunci-Penjadwalan, MTS Negeri 1 Pangkalpinang, Algoritma Genetika

\section{PENDAHULUAN}

Penjadwalan pada MTS Negeri 1 Pangkalpinang masih dilakukan secara manual. Penelitian ini banyak sudah pernah dilakukan peneliti lain dengan algoritma yang sama tentang penjadwalan matakuliah sedangkan ini penjadwalan tentang matapelajan yang pengerjaan algoritma untuk penyusunan jadwalnya hampir sama, dimana terdapat ruang, waktu, mata pelajaran [1] tetapi yang membedakan yaitu data guru dimana pada MTS Negeri 1 ini waktu pengajaran guru telah ditentukan oleh departemen agama bukan lagi ditentukan oleh pihak sekolah. Penjadwalan pada MTS Negeri 1 Pangkalpinang sama halnya dengan penjadwalan pada penelitian[2], tetapi yang membedakan adalah setiap guru memiliki jam mengajar yang maksimal sesuai dengan peraturan dari departemen agama. Setiap semester biasanya pihak yang mengurus jadwal harus membuat dengan teliti dimana setiap guru memiliki batas jam mengajar yang sudah ditentukan oleh departemen agama, kelas yang terbatas serta waktu mengajar yang telah di tentukan sehingga membutuhkan ketelitian dalam penyusunan jadwal. guru yang ada pada MTS Negeri 1 juga memiliki keterbatasan dimana guru yang ada kadang kala mengajar tidak sesuai dengan kompetensi masing-masing contoh dimana guru A kompetensi yaitu di bidang ekonomi tetapi mengajar mata pelajaran geografi atau sebaliknya sehingga tim pembuat jadwal harus menentukan jadwal masing-masing guru dengan teliti agar masing-masing guru mengajar sesuai dengan kompetensi masing-masing, untuk membuat jadwal tersebut membutuhkan waktu yang cukup lama dengan teliti dan terkadang menyusun jadwal ulang jika tidak sesuai.

Dari permasalahan di atas penulis melakukan inovasi untuk mempermudah tim penyusun jadwal pada MTS Negeri 1 Pangkalpinang yaitu menyusun jadwal dengan menggunakan algoritma genetika yang bertujuan untuk memudahkan tim penjadwalan dalam mengoptimalkan jadwal pelajaran dengan menggunakan algoritma genetika.

Algoritma Genetika merupakan salah satu algoritma optimasi yang cukup handal dan sering dipakai dalam penjadwalan [3][4][5]. Algoritma genetika yang menghitung jumlah populasi, kromosom, hitung fitness tiap kromosom, seleksi, pindah silang dan mutase dilakukan dalam bertahap [6], langkah yang lakukan pada penelitian lain yaitu input parameter, populasi awal, crossover, mutasi, evaluasi dan seleksi populasi baru [7]. Dari kutipan tersebut 


\section{METODOLOGI PENELITIAN}

\section{A. Algoritma Genetika}

Algoritma Genetika merupakan metode yang layak dan efektif dalam mengatasi masalah penjadwalan [8]. Algoritma genetika menghasilkan solusi optimal yang sangat berguna pada penyelesaian masalah dengan banyak obyektif, serta dapat digunakan menyelesaikan masalah yang kompleks dengan banyak variabel [9] Adapun tahapan genetika yaitu [2]

\section{1) Pembentukan populasi}

Proses ini merupakan proses yang digunakan untuk membangkitkan populasi awal secara random sehingga didapatkan solusi awal. Populasi awal ini dibangkitkan secara random sehingga diperoleh solusi awal. Populasi ini sendiri terdiri atas sejumlah kromosom yang mempresentasikan solusi yang diinginkan.

TABEL 1. CONTOH MODEL KROMOSOM [2]

\begin{tabular}{|l|l|l|l|l|l|l|l|}
\hline \multicolumn{3}{|c|}{ Jam 1 } & \multicolumn{3}{c|}{ Jam 2 } \\
\hline \multicolumn{2}{|c|}{ R1 } & \multicolumn{2}{c|}{ R2 } & \multicolumn{2}{c|}{ R3 4} \\
\hline Mapel & Guru & Mapel & Guru & Mapel & Guru & Mapel & Guru \\
\hline
\end{tabular}

Pada tabel 1 merupakan kombinasi jam dan ruang belajar dilakukan pada 5 hari (senin-jumat) dan jumlah ruang terdiri dari 2 di masing-masing kelasnya. Mata pelajaran menempati susunan jam dan ruang yang tersedia kemudian dilakukan penentuan pengecekan bentrok antar guru.

Inisialisasi koromosom membantu dalam mendefenisikan Kromosom awal.

Panjang kromosom $=$ jumlah kelas $\mathrm{X}$ jumlah jam pada proses belajar mengajar dalam 1 minggu

Panjang kromosom $=6$ X 25 = 150 gen.

Setiap gen memiliki 2 parameter yaitu mata pelajaran dan guru. Parameter ini berguna untuk pengecekan nilai fitness.

\section{2) Evaluasi Fitness}

Proses ini merupakan proses untuk mengevaluasi setiap populasi dengan menghitung nilai fitness setiap kromosom dan mengevaluasinya sampai terpenuhi kriteria berhenti. Suatu individu dievaluasi berdasarkan suatu fungsi tertentu sebagai ukuran performansinya. Didalam evolusi alam, individu yang bernilai fitness rendah akan mati. Pada masalah optimasi, jika solusi yang dicari adalah memaksimalkan sebuah fungsi $\mathrm{h}$ (dikenal sebagai masalah maksimasi), maka nilai fitness yang digunakan adalah nilai dari fungsi $\mathrm{h}$ tersebut, yakni fitness $\mathrm{f}=$ $\mathrm{h}$.

Fitness $=1 /(1+$ aturan $1 *$ pinalti $1+$ aturan $2 *$ pinalti $2+\ldots \ldots \ldots)$

TABEL 2. ATURAN DAN NILAI PINALTI [2]

\begin{tabular}{|c|c|}
\hline Aturan & Nilai Pinalti \\
\hline Bentrok jam mengajar guru & 1 \\
\hline
\end{tabular}

\section{3) Seleksi}

Proses seleksi merupakan proses untuk menentukan individu-individu mana saja yang akan dipilih untuk dilakukan crossover. Ada beberapa jenis metode seleksi yang biasa digunakan diantaranya yaitu : Metode yang menirukan permainan roulette-wheel dimana masing-masing kromosom menempati potongan lingkaran pada roda roulette secara proporsional sesuai dengan nilai fitnessnya. Seleksi Rangking Proses dimulai dengan merangking atau mengurutkan kromosom di dalam populasi berdasarkan fitnessnya kemudian memberi nilai fitness baru berdasarkan urutannya.

\section{4) CrossOver}

Proses crossover ini merupakan proses untuk menambah keanekaragaman string dalam satu populasi. Operator pindah silang mempunyai peran yang paling penting dalam algoritma genetik karena didalamnya terdapat proses perkawinan (persilangan) gen antara dua individu (parent) yang menghasilkan dua individu baru (offspring) pada generasi berikutnya.

TABEL 3. PROSES CROSSOVER (KAWIN SILANG) [2]

\begin{tabular}{|l|l|l|l|l|l|l|l|l|}
\hline Induk 1 & 4,58 & 2,23 & 7,38 & 12,57 & 4,59 & 7,2 & 12,37 & 9,32 \\
\hline Inde _2 & 10,18 & 8,43 & 6,8 & 5,29 & 4,8 & 7,15 & 9,25 & 1,37 \\
\hline
\end{tabular}

\begin{tabular}{|l|l|l|l|l|l|l|l|l}
\hline Induk_2 & 10,18 & 8,43 & 6,8 & 5,29 & 4,8 & 7,15 & 9,25 & 1,37 \\
\hline
\end{tabular}

\begin{tabular}{l|l|l|l|l|l|l|l|l} 
Anak_1 & 4,58 & 2,23 & 7,38 & 12,57 & 4,8 & 7,15 & 9,25 & 1,37 \\
\hline Ana__2 & 10,18 & 8,43 & 6,8 & 5,29 & 4,59 & 7,2 & 12,37 & 9,32 \\
\hline
\end{tabular}

\begin{tabular}{l|c|c|c|c|c|c|c|c|}
\hline Anak_2 & 10,18 & 8,43 & 6,8 & 5,29 & 4,59 & 7,2 & 12,37 & 9,32 \\
\hline
\end{tabular}

\section{5) Mutasi}

Mutasi merupakan proses mengubah nilai dari satu atau beberapa gen dalam suatu kromosom. Mutasi menciptakan individu baru dengan melakukan modifikasi satu atau lebih gen dalam individu yang sama. Mutasi berfungsi untuk menggantikan gen yang hilang dari populasi selama proses seleksi serta menyediakan gen yang tidak ada dalam populasi awal.

TABEL 4. PROSES MUTASI [2]

\begin{tabular}{|c|c|c|c|c|c|c|c|}
\hline Sebelum & 5,9 & 10,52 & 8,41 & 7,19 & 4,24 & 11,26 & 1,22 \\
\hline Sesudah & 5,9 & 10,52 & 5,2 & 7,19 & 4,24 & 4,3 & 1,22 \\
\hline
\end{tabular}

\section{6) Kriteria Berhenti}

Kriteria berhenti merupakan kriteria yang digunakan untuk menghentikan proses Algoritma Genetika yang merupakan tujuan yang ingin dicapai dari proses tersebut.

\section{7) Hasil}

Hasil merupakan solusi optimum yang didapat dengan menggunakan Algoritma Genetika.

\section{B. Analisis Sistem Usulan}

Analisis sistem usulan merupakan sistem yang dibuat untuk mengoptimasikan sistem penjadwalan dengan algoritma genetika. Dapat dilihat pada gambar 1 dibawah ini:

Gambar 1 menjelaskan fungsi dari sistem yang diusulkan yang terdiri dari data guru, hari, jam, kelas, mapel, ketersediaan pengampu mapel, proses genetika dan jadwal.

Gambar 2 menjelaskan dimana admin mengisi jumlah populasi, probalitas, jumlah generasi, tahun ajaran dan semester yang untuk di proses di sistem yang di ambil dari masing-masing tabel pada database. Proses class diagram dapat di lihat gambar 3. 


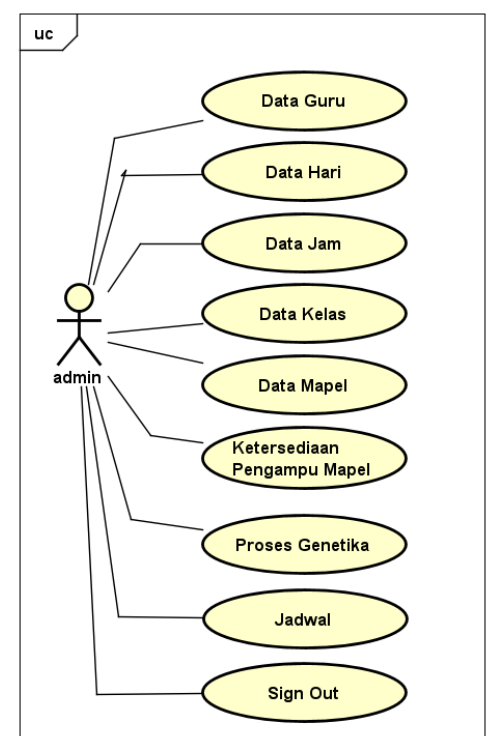

Gambar 1. Analisis Sistem Usulan

Proses aktivitas gentika dapat dilihat di gambar 2.

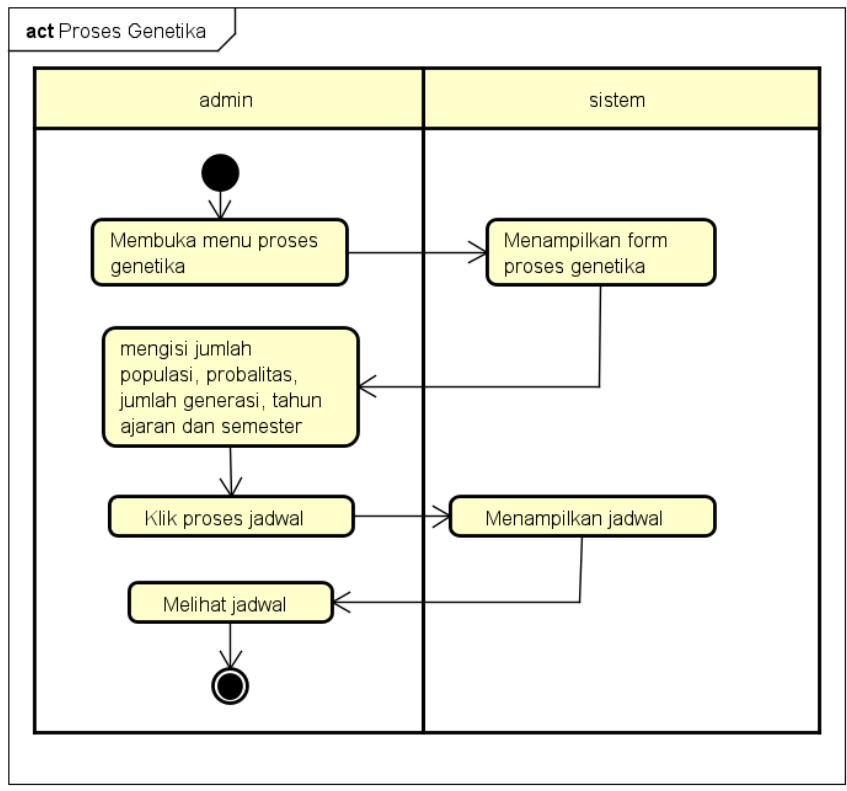

Gambar 2. Activity Diagram Proses Genetika

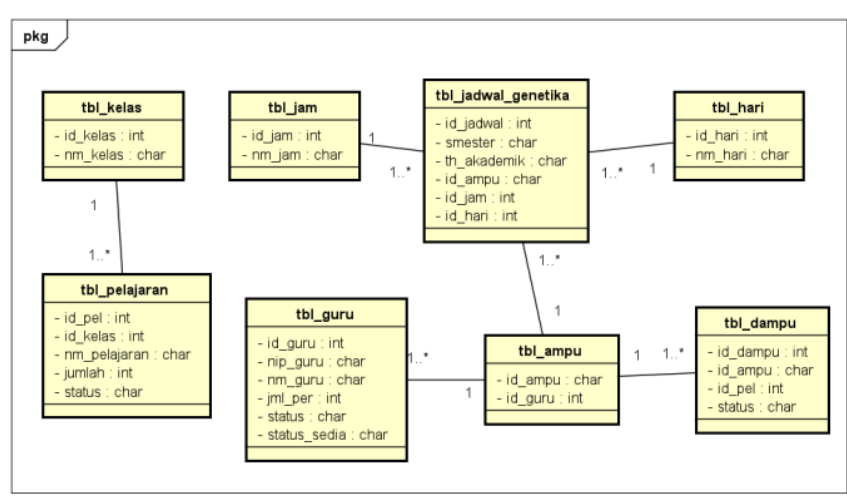

Gambar 3. Class Diagram
Class diagram tersebut ada beberapa class yaitu pelajaran, kelas, jam, jadwal genetika, hari, guru, ampu, dan dampu dimana setiap class saling terkait satu sama lain. Alur proses genetika yang menjelaskan alur program yang dapat dilihat pada gambar 4.

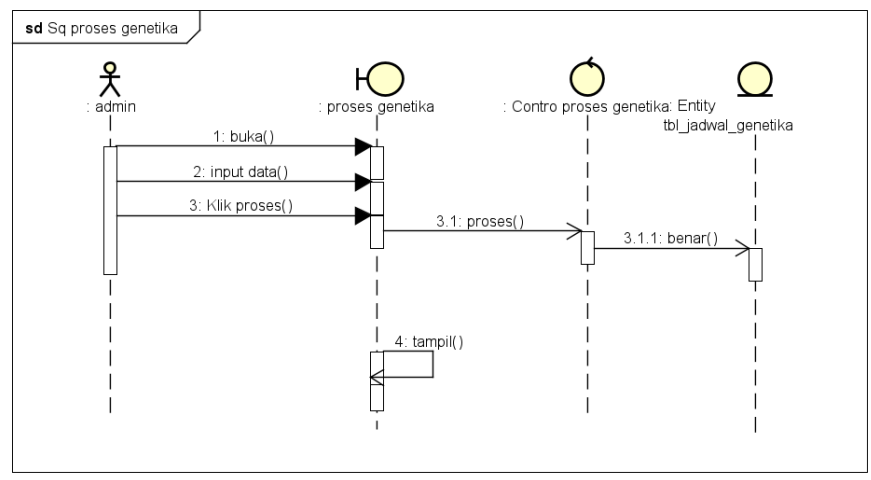

Gambar 4. Sequence Diagram Proses Genetika

\section{Analisis Penjadwalan}

Adapun analisis penyelesaian dari penelitian ini seperti gambar 5 dibawah ini.

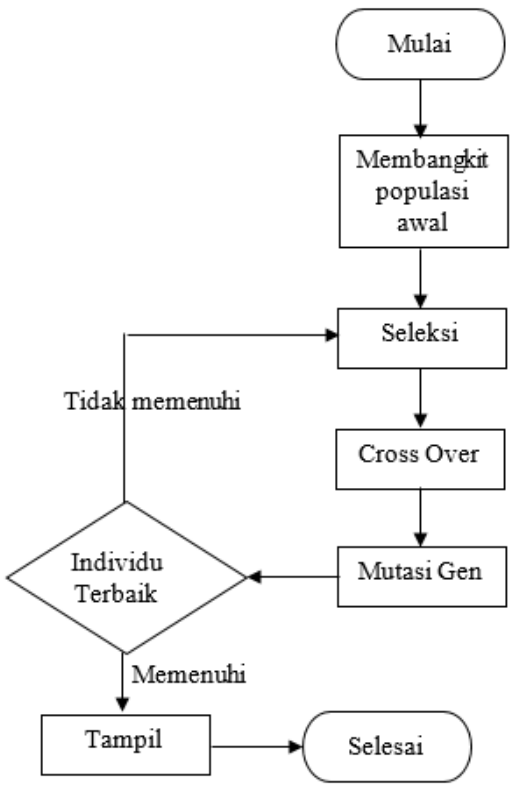

Gambar 5. Flowchart Algoritma Genetika untuk Penjadwalan

Dari gambar 5 di atas menjelaskan langkah-langkah yang dilakukan saat terbentuknya jadwal.

\section{Perhitungan Manual Algoritma Genetika}

Pertama Membangkitkan populasi awal yang terdiri dari jumlah kromosom.

Kromosom $1=\{[0,2,4],[1,5,13], \ldots[20,4,0]\}$

Dapat dilihat Kromosom 1 memiliki 20 gen yang artinya terdapat 20 pelajaran. Setiap gen adalah kombinasi [mapel, ruang, waktu]. Dalam gen data dimasukkan dalam angka 
(indeks dimulai dari 0). Gen [0, 2, 4] artinya pelajaran ke satu, ruang ke 2 dan waktu ke 4 . Tapi harus diperhatikan semakin banyak kromosom dibangkitkan maka semakin berat dam lambat proses generate jadwal.

Kedua melakukan seleksi dimana proses seleksi melakukan pemilihan kromosom mana yang digunakan untuk proses algoritma selanjutnya. Seleksi dilakukan berdasarkan nilai fitness kromosom. Misalnya ada 2 kromosom yang dibangkitkan dengan masing-masing fitness

Kromosom 1 = 0,8 dan Kromosom $2=0,3$

Maka total nilai fitness $=0,8+0,3=1,1$

Probabilitas $1=0,8 / 1,1=0,73$

Probabilitas $2=0,3 / 1,1=0,27$

Dari Probabilitas dapat menghitung jatah masing-masing individu pada angka 1 sampai 100 yaitu dengan mencari komulatif dari probabilitas.

$$
\begin{aligned}
& \text { PK1 }=0+0,73=0,73 \\
& \text { PK2 }=0,73+0,27=1
\end{aligned}
$$

Langkah berikut membangkitkan bilangan acak antara 0 1 sejumlah kromosom. Dari bilangan acak yang di hasilkan maka algoritma ini menentukan individu mana yang terpilih dalam proses seleksi. Jika bilangan pertama 0,3 maka kromosom 1 terpilih (kromosom 1 antara $0-0,73$ ), jika bilangan berikutnya 0,92 maka 2 terpilih (kromosom 2 antara 0,73 - 1), Kromosom yang di pilih sebanyak jumlah kromosom awal tapi bisa saja ada kromosom yang sama terpilih dan tidak terpilih.

Ketiga crossover atau pindah silang yaitu pertukaran gen antara 2 buah kromosom. Kromosom yang menjadi induk dipilih secara acak sebanyak crossover rate yang sudah diatur di awal. Misal ada 10 kromosom dengan dengan CR 70\%, maka induk yang digunakan adalah 7. Dari 7 induk ini akan dipasangkan dua dua yang menghasilkan 1 individu baru. Pasangan induk yang terjadi adalah 7 pasang yaitu, induk1 dan induk 2 , induk 2 dan induk 3 , dan seterusnya sampe induk 7 dengan induk 1 . Setiap induk akan berpasangan 2 kali.

Langkah terakhir mutasi atau pergantian gen. Gen yang diganti hanya kelas dan waktu saja. Jumlah gen yang diganti tergantung Mutation Rate (MR). contoh ada 2 kromosom dengan gen 10 masing-masing kromosom, MR 50\% sehingga total gen 2 x 10 (jumlah kromosom $x$ jumlah gen per kromosom) $=20$ gen.

Jumlah mutasi $50 \%$ x $20=10$ gen.

\section{HASIL DAN PEMBAHASAN}

\section{A. Hasil}

Hasil dari sistem penjadwalan yaitu tampilan awal beruapa halaman login seperti gambar 6

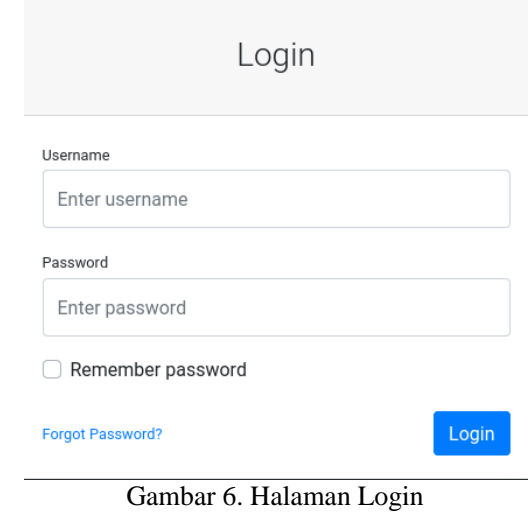

Gambar 6 di atas menjelaskan dimana pengguna harus melalui login terlebih dahulu sebelum masuk ke sistem penjadwalan. Username dan password harus sesuai dengan yang ada di database.

Setelah login berhasil admin dapat mengakses halaman guru seperti gambar 7 di bawah ini.

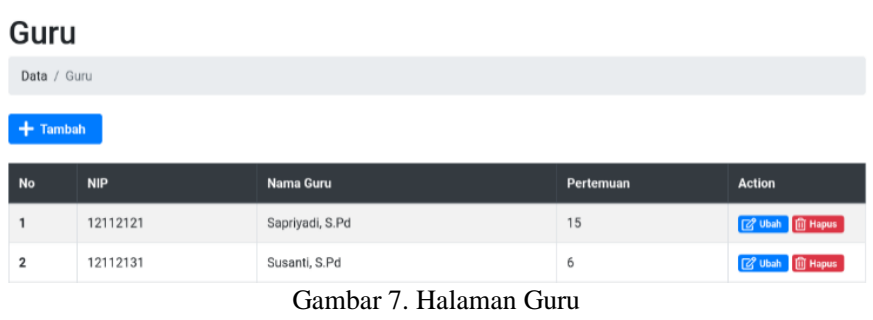

Gambar 7 di atas berfungsi untuk menambahkan data guru yang terdiri dari NIP, Nama, dan pertemuan dalam satu minggu.

Admin juga dapat menambahkan data master hari pada gambar 8 dan menambahkan data jam pada gambar 9 dimana hari dan jam disini di maksud hari dan jam aktif mengajar atau sekolah dalam proses belajar mengajar.

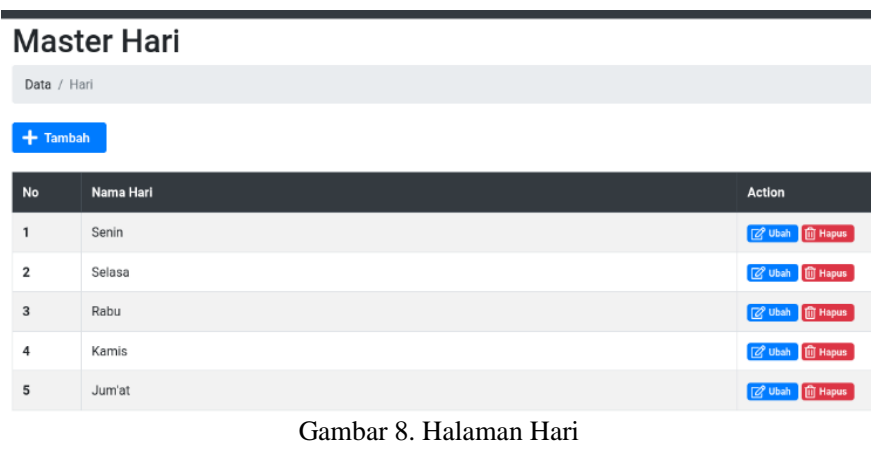

Gambar 8 di atas berfungsi untuk menambah data hari yang terdiri dari Nama Hari yang aktif di sekolah. 


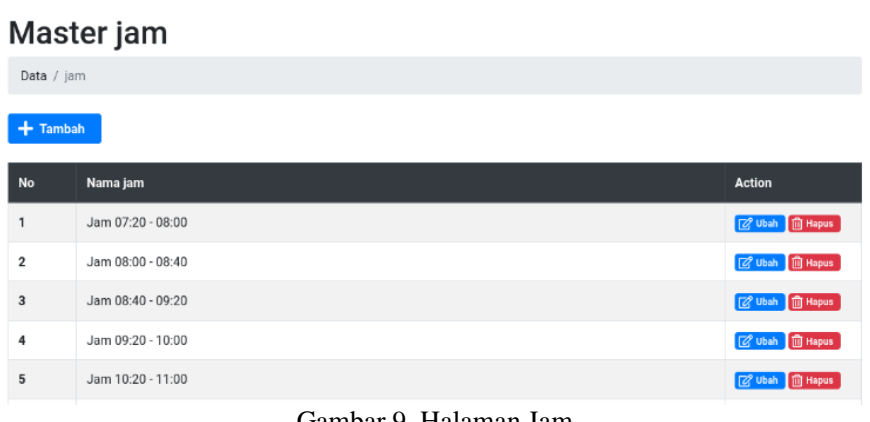

Gambar 9. Halaman Jam

Gambar 9 di atas berfungsi untuk menambahkan jam aktif proses belajar mengajar di sekolah tersebut. Jika ada penambahan kelas baru maka admin dapat menambahkan kelas pada sistem penjadwalan ini seperti gambar 10.

\section{Master kelas}

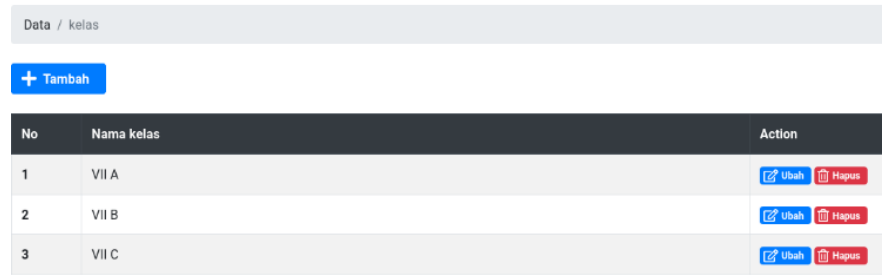

Gambar 10. Halaman Kelas

Gambar $10 \mathrm{di}$ atas berfungsi untuk menampung data semua kelas yang digunakan pada MTS Negeri 1 Pangkalpinang. Hal terpenting dalam penjadwalan yaitu data mata pelajaran dimana admin dapat menambah atau pun menghapus serta mengubah data mata pelajaran di sistem seperti gambar 11.

\section{Data Mata Pelajaran}

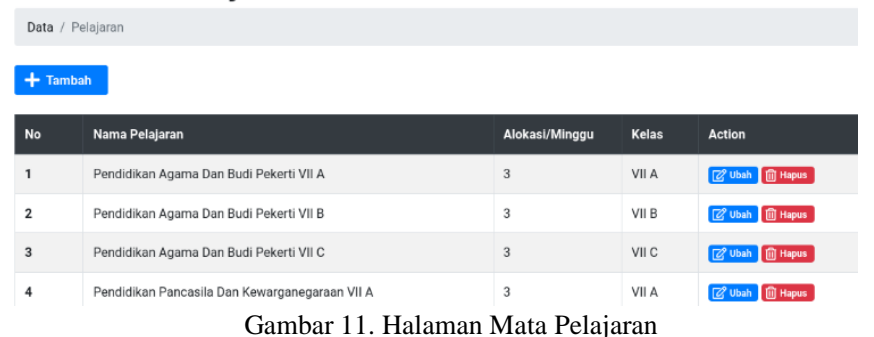

Gambar 11 berfungsi untuk menampung data mata pelajaran untuk semua mata pelajaran yang ada di MTS Negeri 1 Pangkalpinang mulai dari kelas VII sampai dengan mata pelajaran kelas IX. Semua data mata pelajaran akan tertampung di data mata pelajaran.

Proses pembuatan jadwal pada MTS Negeri 1 ini guru mengampu mata pelajaran yang sesuai bidangnya dan ketersediaan guru tersebut dalam mengajar mata pelajaran tersebut dimana admin dapat memasukkan data ketersediaan guru dalam mengampu mata pelajaran seperti gambar 12 .

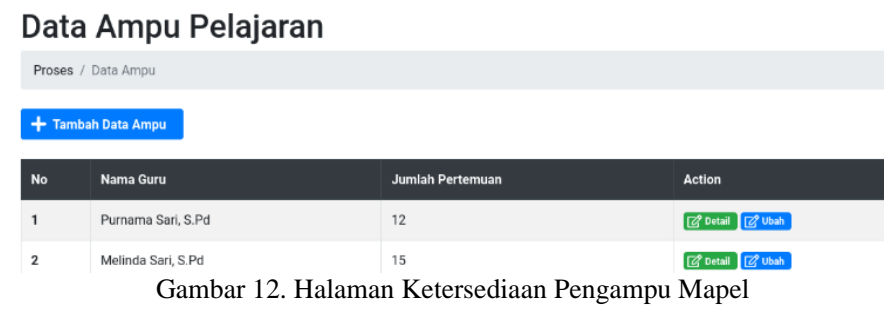

Gambar 12 di atas berfungsi untuk menyimpan ketersediaan guru untuk mengampu mata pelajaran, setiap guru dapat mengampu lebih dari satu mata pelajaran seperti gambar 13 dibawah ini.

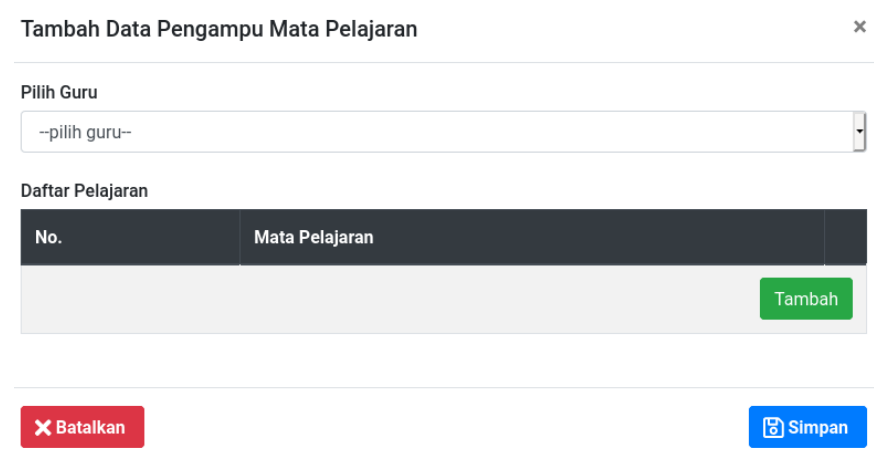

Gambar 13. Halaman tambah pengampu mapel

Gambar 13 berfungsi untuk menambahkan data ketersediaan guru untuk mengampu mata pelajaran. Pada gambar 13 ini guru pengampu dapat mengajar lebih dari satu mata pelajaran.

Pada gambar 12 terdapat action detail yang dapat dilihat pada gambar 14.

\begin{tabular}{|c|c|c|c|}
\hline \multicolumn{4}{|c|}{ Detail Ampu } \\
\hline \multicolumn{4}{|c|}{ Nama Guru : Purnama Sari, S.Pd } \\
\hline No & Mata Pelajaran & Jumlah Pertemuan & Kelas \\
\hline 1 & Bahasa Inggris VII A & 4 & VII A \\
\hline 2 & Bahasa Inggris VII B & 4 & VII B \\
\hline 3 & Bahasa Inggris VII C & 4 & VIIC \\
\hline
\end{tabular}

Gambar 14. Halaman Detail Pengampu

Data detail pengampu ini berfungsi untuk memudahkan admin melihat setiap guru pengampu apa saja mata pelajaran yang akan di ampu oleh masing-masing guru pengampu.

Setelah semua data guru, hari, jam, kelas, mata pelajaran dan ketersediaan guru ada maka admin dapat membuat jadwal pada sistem ini menggunakan algoritma genetika seperti halaman 15. Dimana halaman proses Algoritma genetika di proses oleh bagian akademik untuk membentuk jadwal secara otomatis dengan menginput semester, tahun akademik, jumlah populasi, probalitas CrossOver, Probalitas Mutasi dan Jumlah Generasi, gambar 15. 


\section{Penjadwalan Genetika}

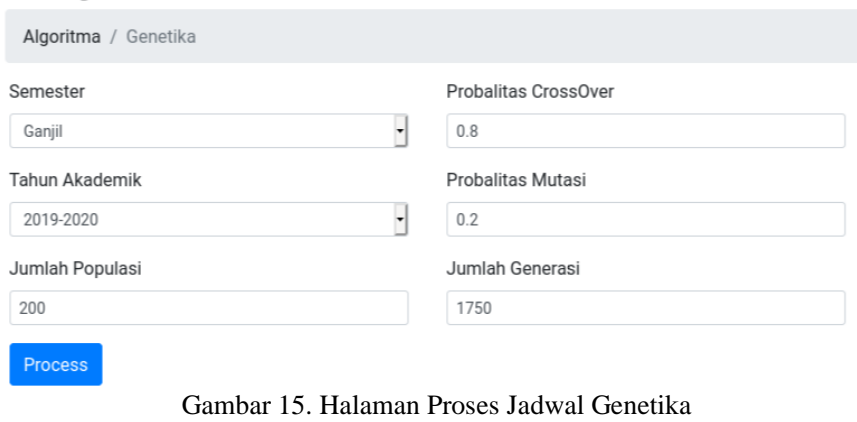

Setelah di klik button proses maka akan terbentuk jadwal seperti gambar 16. Dimana pada halaman jadwal ini berfungsi untuk melihat dan atau mencetak jadwal untuk di bagikan ke guru di MTS Negeri 1 Pangkalpinang.

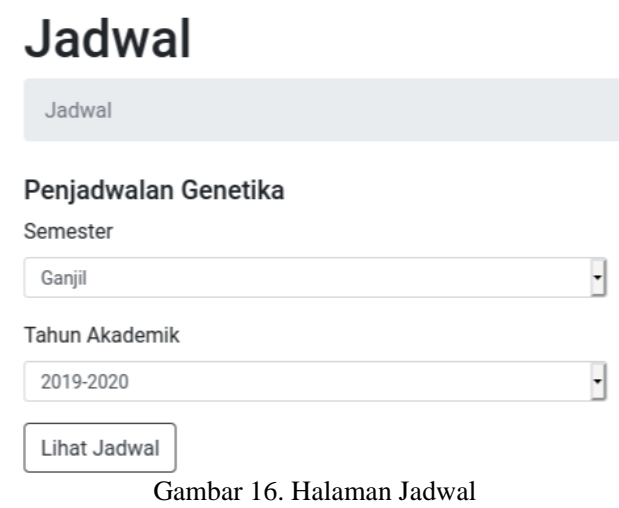

Ketika admin memilih menu jadwal pada gambar 16 maka admin akan memilih semester dan tahun akademik kemudian mengklik lihat jadwal sehingga menampilkan jadwal untuk keseluruhan seperti gambar 17.

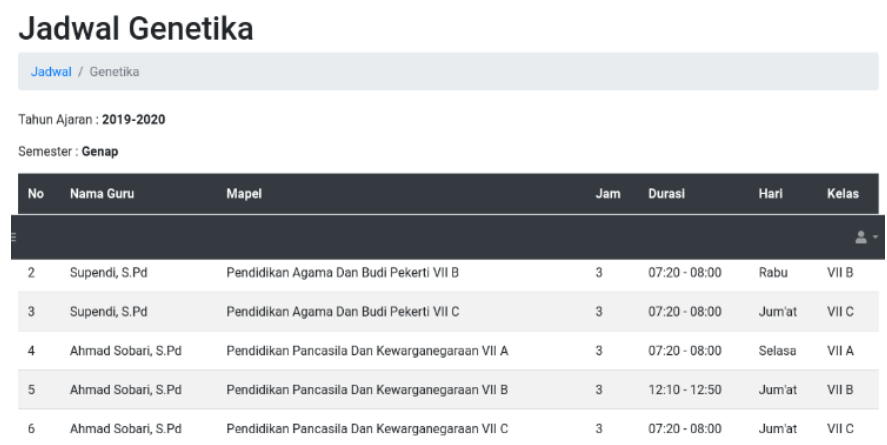

Gambar 17. Halaman Lihat Jadwal

\section{B. Pengujian Sistem}

Pengujian sistem dilakukan dengan 15 data mata pelajaran, 20 data mata pelajaran, 25 data dan 30 data mata pelajaran dengan penjabaran seperti berikut:

Pertama percobaan dengan 15 data mata pelajaran membutuhkan waktu 19,55811882019 detik hingga terbentuknya jadwal. dari waktu tersebut tidak adanya jadwal yang bentrok baik dari segi guru, jam, hari, dan kelas ajar, yang dapat dilihat pada gambar 18 .

\section{Penjadwalan Genetika}

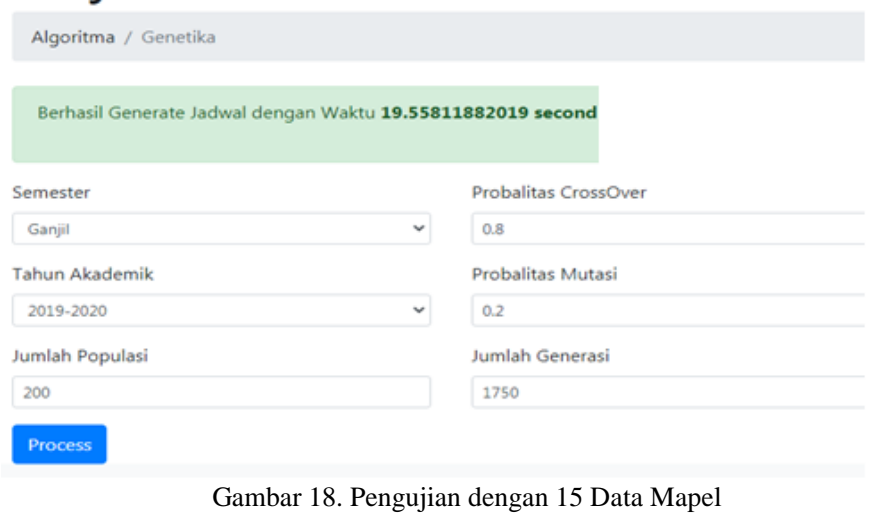

Kedua, Percobaan dengan 20 data mata pelajaran membutuhkan waktu 42,152410984039 detik untuk membentuk jadwal yang dapat dilihat pada gambar 19.

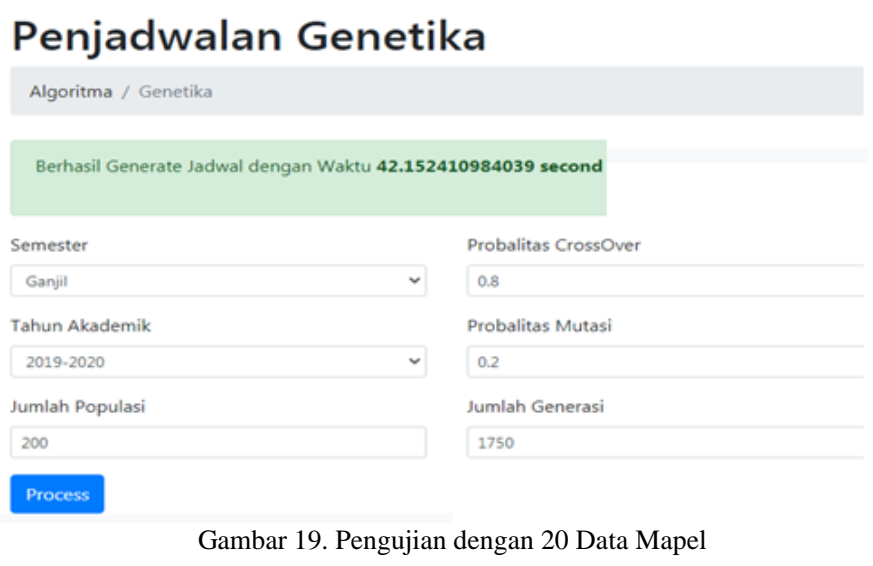

Ketiga, Percobaan dengan 25 data mata pelajaran. Pengujian dengan 25 data mapel membutuhkan waktu 94,069380044937 detik untuk membentuk jadwal pada gambar 20.

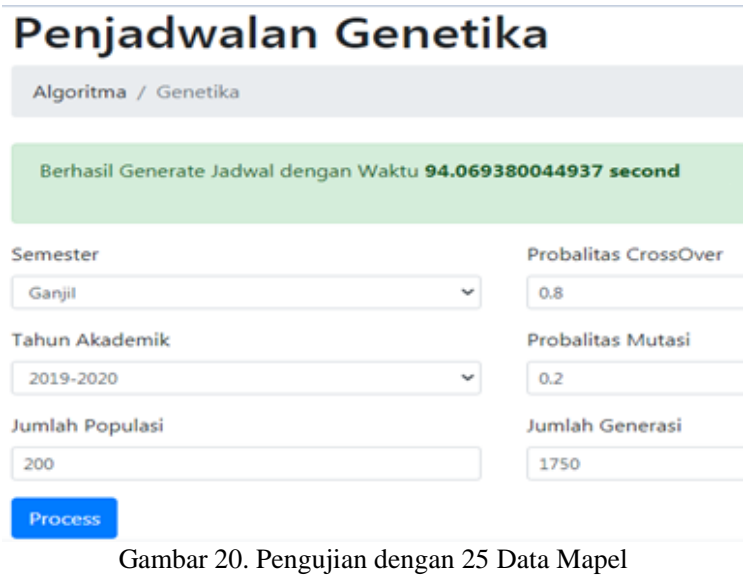

Keempat, Percobaan dengan 30 data mata pelajaran. Pengujian dengan 30 data mapel membutuhkan waktu 471,59997391701 detik untuk membentuk jadwal pada gambar 21. 


\section{Penjadwalan Genetika}

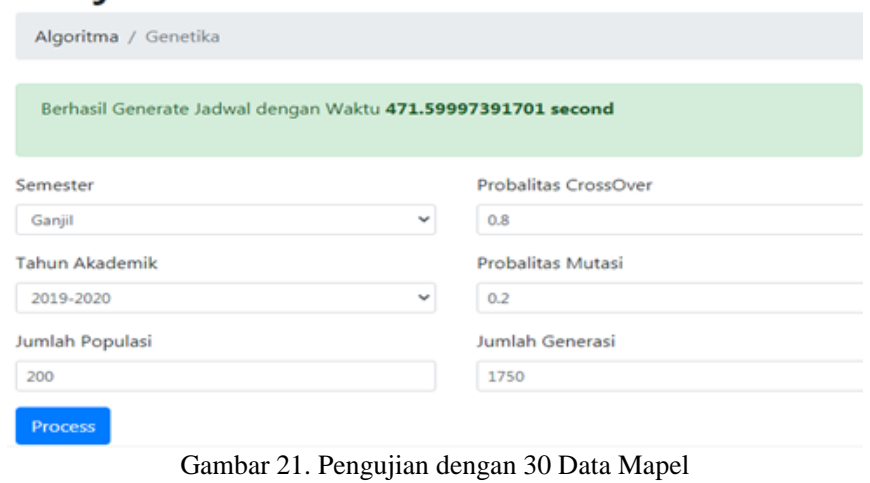

Dari ke empat pengujian tersebut dengan data yang berbeda dengan 15 data, 20 data, 25 data dan 30 data mata pelajaran dapat dilihat perbedaan pada grafik dibawah ini.

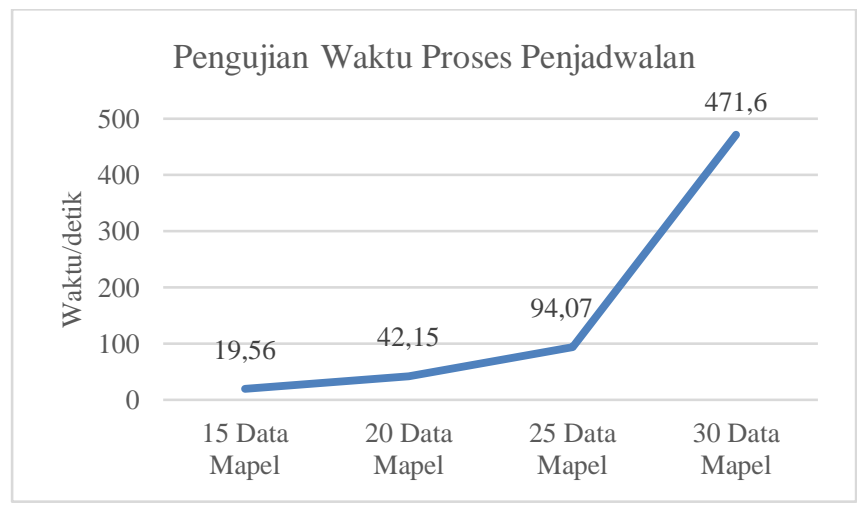

Gambar 22. Grafik Pengujian Proses Penjadwalan

\section{PENUTUP}

Adapun hasil dari optimasi penjadwalan ini dengan algoritma genetika dapat ditarik kesimpulan yaitu pertama sistem yang telah dilakukan uji coba dengan empat data yaitu dengan $15,20,25$ dan 30 data matapelejaran hanya membutuhkan waktu masing-masing percobaan yaitu 15 data butuh waktu 19,56 detik, 20 data butuh waktu 42,15 detik, 25 data butuh waktu 94,07 detik dan 30 data butuh waktu 471,60 detik sehingga algoritma genetika ini sangat efektif untuk penjadwalan yang hanya membutuhkan waktu tidak melebih 8 menit untuk keempat data tersebut. Keempat data tersebut dilakukan uji coba dengan 15, 20, 25 dan 30 data tidak ada terjadinya bentrok sehingga algoritma ini tepat untuk digunakan dalam memproses penjadwalan pada MTS Negeri 1 Pangkalpinang.

\section{DAFTAR PUSTAKA}

[1] A. T. Ma'arif and D. P. Pamungkas, "Penerapan Metode Algoritma Genetika untuk Optimasi Penjadwalan Mata Kuliah," Semin. Nas. Inov. Teknol. UN PGRI Kediri, pp. 93-97, 2018.

[2] S. Ni Luh Gede Pivin, S. I Made, and D. Suta, "Penerapan Algoritma Genetika Untuk Penjadwalan Mata Pelajaran," J. Appl. Intell. Syst., vol. 1, no. 3, pp. 220-233, 2016.

[3] D. Oktarina and A. Hajjah, "Perancangan Sistem Penjadwalan Seminar Proposal dan Sidang Skripsi dengan Metode Algoritma Genetika," JOISIE (Journal Inf. Syst. Informatics Eng., vol. 3, no. 1, p. 32, 2019, doi: 10.35145/joisie.v3i1.421.

[4] A. Hajjah, "Penerapan Algoritma Genetika dalam Optimasi Penjadwalan Proyek," vol. 2, no. 1, pp. 50-55, 2020.

[5] A. Josi, "Implementasi Algoritma Genetika Pada Aplikasi Penjadwalan Perkuliahan Berbasis Web Dengan Mengadopsi Model Waterfall," J. Inform. J. Pengemb. IT, vol. 02, no. 02, pp. 77-83, 2017, doi: 10.30591/JPIT.V2I2.517.G554.

[6] Y. Elva, "Sistem Penjadwalan Mata Pelajaran Menggunakan Algoritma Genetika," J. Teknol. Inf., vol. 3, no. 1, p. 49, 2019, doi: 10.36294/jurti.v3i1.687.

[7] R. M. Puspita, A. Arini, and S. U. Masrurah, "Pengembangan Aplikasi Penjadwalan Kegiatan Pelatihan Teknologi Informasi Dan Komunikasi Dengan Algoritma Genetika (Studi Kasus: Bprtik)," J. Online Inform., vol. 1, no. 2, pp. 76-81, 2016, doi: 10.15575/join.v1i2.43.

[8] Monalisa and Diana, "OPTIMASI PENJADWALAN SHIFT KERJA MENERAPKAN ALGORITMA GENETIK," Bina Darma Conf. Comput. Sci., no. Vol 2 No 2 (2020): Bina Darma Conference on Computer Science (BDCCS), pp. 453-460, 2020, [Online]. Available: http://conference.binadarma.ac.id/index.php/BDCCS/article/view/1318.

[9] A. Nugroho, W. Priatna, and I. Romli, "Implementasi Algoritma Genetika Untuk Optimasi Penjadwalan Mata Kuliah," J. Teknol. dan Ilmu Komput. Prima, vol. 1, no. 2, pp. 35-41, 2018, doi: 10.34012/jutikomp.v1i2.238. 